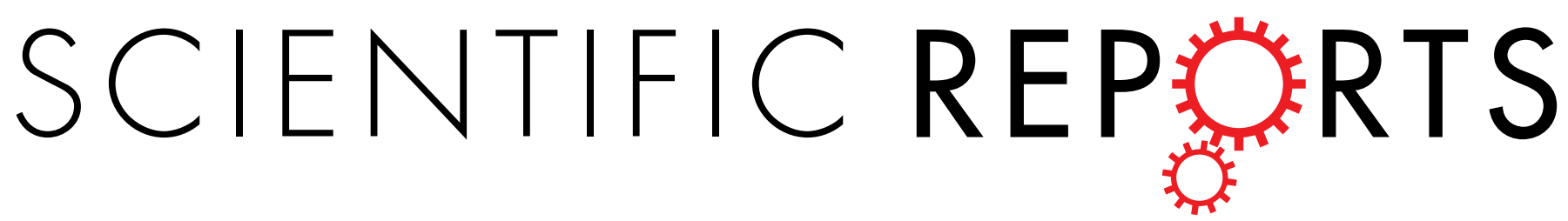

\title{
OPEN Corrigendum: Pre-formulation and systematic evaluation of amino acid assisted permeability of insulin across in vitro buccal cell layers
}

Affiong lyire, Maryam Alaayedi \& Afzal R. Mohammed

Scientific Reports 6:32498; doi: 10.1038/srep32498; published online 01 September 2016; updated on 14 October 2016

The original version of this Article contained a typographical error in the spelling of the author Maryam Alaayedi, which was incorrectly given as Maryam Alayedi. This error has now been corrected in the PDF and HTML versions of the Article.

(c) (i) This work is licensed under a Creative Commons Attribution 4.0 International License. The images or other third party material in this article are included in the article's Creative Commons license, unless indicated otherwise in the credit line; if the material is not included under the Creative Commons license, users will need to obtain permission from the license holder to reproduce the material. To view a copy of this license, visit http://creativecommons.org/licenses/by/4.0/

(c) The Author(s) 2016 